\title{
Uočiti, pratiti i liječiti najslabije u zajednici prema Amoris laetitia
}

\author{
Pero ARAČIĆ* \\ • https://doi.org/10.31823/d.28.3.5 • \\ UDK: 272-45-053.2-058.836 • Prethodno priopćenje \\ Primljeno: 30. listopada 2019. Prihvaćeno: 8. rujna 2020.
}

*Prof. dr. sc. Pero Aračić,

Katolički bogoslovni fakultet u Đakovu

Sveučilišta J.J.

Strossmayera u Osijeku,

Petra Preradovića 17, p. p. 54, 31400 Đakovo, Hrvatska, pero.aracic@os.t-com.hr

Sažetak: Rad iznosi činjenično stanje pošasti rastava i razvoda u Hrvatskoj te na temelju razgovora koji su objavljeni u autorovoj studiji o tim procesima na poseban način obraduje utjecaj istih na supružnike i na poseban način na djecu iz ta$k$ vih slomljenih brakova i obitelji. Donose se $i$ istraživanja o prenošenju kulture rastave $i$ razvoda na sljedeće generacije. Rad se zajedno s Amoris laetitia pita što činiti i traži od zajednice da pomogne tom silnom broju traumatiziranih, i to procesima opraštanja i pomirenja, kao i integracijom u zajednice te velikom solidarnošću da im budu blizu i od pomoći. Naravno, tu su na raspolaganju i crkvene stručne pravne službe s kojima treba provesti analizu o bračnoj i obiteljskoj situaciji išto crkveno zakonodavstvo preporučuje. U svim tim procesima, koji su često dugotrajni, preostaje im vjernicka bliskost $i$ solidarnost.

Ključne riječi: rastave i razvodi, djeca iz takvih brakova i obitelji, proživljavanja svih zahvaćenih, put opraštanja, opraštanje i pomirenje, crkvena integracija.

\section{Uvod}

Na simpoziju pastoralnih teologa istočne i srednje Europe $\mathrm{u}$ Linzu 2014. godine u pastoralnom centru u tvornici željezare bila je tema Crkva kao »poljska bolnica $\ll$. To nije još išlo u moju glavu i moje koncepte, pa sam u propovijedi javno rekao da mi taj pojam baš ne sjeda.

U apostolskoj pobudnici Evangelii gaudium - Radost evandelja ${ }^{1}$, od br. 209. do 216. govori se o brizi za ranjive i na-

${ }^{1}$ FRANJO, apostolska pobudnica Evangelii gaudium - Radost evandelja, Zagreb, ${ }^{2}$ 2014. (=EG). 
braja ih se. Tako Evangelii gaudium br. 210. kaže: »Prijeko je potrebno posvetiti pozornost novim oblicima siromaštva i krhkosti, u kojima smo pozvani prepoznati Krista patnika, premda nam to na prvi pogled ne donosi opipliive i neposredne koristi. Tu mislim na beskućnike, ovisnike, izbjeglice, urođenike, starije koji su sve osamljeniji i napušteniji i mnoge druge. « Evangelii gaudium br. 212. govori o ženama žrtvama nasilja, zatim br. 213. o prekidima života začetih - abortusima onih koji su najbespomoćniji i najneviniji.

Kasnije sam počeo promišljati o broju pogođenih vjernika, o njihovoj i našoj izranjenosti, a posebice o nekim skupinama, koliko ta njihova patnja traje. I tako sam došao do istine o toj vrsti patnje o kojoj su mi drugi rekli da im je trebalo od jedne do deset godina da nekako stanu na noge, a onda neki kažu da ne mogu nikako riješiti tu svoju situaciju.

Onda opet pred oči dolazi misao iz apostolske pobudnice Amoris laetitia ${ }^{2}$ : $\gg$ Crkva mora brižno i pažljivo pratiti svoju najslabiju djecu, obilježenu izgubljenom i ranjenom ljubavlju, vraćajući povjerenje i nadu, poput svjetionika neke luke ili baklje koja se nosi među ljude da prosvijetli one koji su skrenuli s pravoga puta ili se nalaze usred oluje. Ne zaboravimo da je često rad Crkve nalik onom u poljskoj bolnici.«U kontekstu današnjega promišljanja izabrao sam četiri kategorije pogođenih. Riječ je o rastavljenima i razvedenima, razvedenima i ponovno civilno vjenčanima, o djeci iz tih brakova (gotovo polovica brakova imala je jedno ili dvoje djece!) te o djeci rođenoj bez braka. Ujedno se usuđujem upitati sve nas: Koliko smo svjesni broja pogođenih u konkretnoj povjerenoj zajednici i posljedica za njihov osobni život, ali i život crkvene i narodne zajednice?

Naišao sam na ovaj naslov: Trauma - rana koju vrijeme ne liječi ${ }^{3}$, u kojem se poriče onu narodnu poslovicu kako vrijeme liječi sve rane. Trauma je dugotrajniji stres ili niz stresova kojih se ne uspijevamo riješiti. Barem ne tek čekajući da vrijeme odmakne. I onda ostaje rana i ranjivost $s$ kojim se mora naučiti živjeti. Kako? Koje procese valja proći? Na što treba računati? ${ }^{4}$

\footnotetext{
${ }^{2}$ ISTI, Amoris laetitia - Radost ljubavi, Zagreb, 2016., br. 291 (= AL).

${ }^{3}$ N. JURIĆ, Trauma - rana koju vrijeme ne liječi, u: Vjesnik Đakovačko-osječke nadbiskupije i Srijemske biskupije 12(2016.) 47-48.

${ }^{4}$ Veći dio teksta, skraćen i prilagođen, nadahnut je studijom: P. ARAČIĆ, Trauma rastave i razvoda braka i obitelji. Uzroci i posljedice. Kako dalje?, Osijek, 2016., 17-27., 143-179., ali nadopunjen najnovijim papinskim dokumentima i promišljanjem o integraciji u župne zajednice te svježim državnim statistikama.
} 


\section{Ranjeni brakovi: pojmovi rastava i razvod $^{5}$}

Rastava je proces koji je započeo prije negoli su se parovi fizički razišli i sve što je dovelo do te odluke. $U$ taj dio procesa pripada i ulaženje u još zamršeniji proces, a to je priprava samoga formalnoga razvoda. I samim formalnim razvodom ostaje niz teškoća i pitanja: Zašto je do toga došlo? Tko je kriv? Tko je više kriv? Tko će uzdržavati i odgajati djecu? Kako ostvarivati prava svakoga roditelja s obzirom na djecu? Hoće li se ostvarivati materijalne obveze s obzirom na djecu? I još mnoštvo pitanja i dilema. I to je niz stresova. I sve se to može nazvati traumom i jest trauma.

\section{Statistički podatci za Hrvatsku: sklopljeni i razvedeni brakovi}

Zabrinjavajući je trend opadanja sklapanja brakova u Hrvatskoj. Od 1950. do 2012. godine sklapanje brakova na godišnjoj razini smanjeno je s obzirom na 1950. godinu za 17 672, odnosno za oko $35 \%$. Istovremeno se već od 1970. broj razvoda ustalio na oko 5000 brakova, što je 1970. značilo da se razvodi svaki 7. brak, a 2012. to je svaki 3,5. brak. Ovdje ne ulazimo u prikazivanje teritorijalne raspoređenosti, ali je općepoznato da su u gradovima razvodi češći nego u nekim drugim sredinama. Ujedno treba reći da taj broj razvedenih uključuje sve: i one koji se prvi put razvode, kao i one koji su to učinili više puta. Isto tako primjetno je da do razvoda

\footnotetext{
${ }^{5}$ U smislu Obiteljskog zakona obitelj čine i žena i muškarac koji su živjeli zajedno u bračnoj ili izvanbračnoj zajednici, djeca svakoga od njih i njihova zajednička djeca, ako su nakon prekida bračne ili izvanbračne zajednice povod sukoba bili bivši bračni ili izvanbračni odnosi.

Rastava je vrijeme od prekida zajedničkoga života pa do sudskoga razvoda nekoga braka. Razvod dakle nastupa kad se neki brak sudski pravomoćno prekine, čime prestaje postojati bračna zajednica ili brak. Kad je riječ o statistikama, onda vidimo da se govori samo o razvedenim brakovima, jer broj rastavljenih nije moguće ustanoviti dok se ne dogodi službeni razvod ili se posebno ne počnu voditi moguće sudske presude i na razini rastave. Tako Nenad HLAČA kaže: »Rastava braka je promjena statusa bračnih drugova na temelju sudske odluke kojom bračni drugovi više nisu dužni živjeti zajedno. Bitna razlika u pravnim sadržajima presude o rastavi i presude o razvodu braka jest činjenica da pri donošenju presude o rastavi braka ne dolazi do prestanka braka.« (Rastava braka, u: Zbornik Pravnog fakulteta u Zagrebu 55(2005.), 780-781., opširnije: 775-800.) Taj proces do razvoda braka može potrajati i više godina. U redovitom govoru upotrebljava se uglavnom riječ rastava.

Ovako prestanak braka definira Obiteljski zakon, čl. 47.: »Brak prestaje poništajem ili razvodom kad presuda suda o poništaju ili razvodu braka postane pravomoćna. Ako brak sklopljen u vjerskom obliku prestane prema odredbi stavka 2. ovoga članka, prestanak braka ne utječe na obveze bračnih drugova koje proizlaze iz propisa vjerske zajednice pred kojom je brak sklopljen.«

U skladu s rečenim upotrebljavat ćemo i sintagmu rastavljen/razveden kojom želimo da se stalno drži na pameti da su postojali procesi prije formalnoga razvoda, kao što mnogi procesi ostaju i iza toga formalnoga čina razvoda. To se sve može uočiti iz priloženih razgovora s pogođenima. Usp. također: A. KORAĆ GRAOVAC, Brak i obitelj kao vrijednost u hrvatskom pravnom sustavu, u: Bogoslovska smotra 85(2015.)3, 799-811.
} 
najčešće dolazi u prvim godinama braka. Može se reći da se više razvoda bilježi u prvih 10-ak godina, a onda opet nakon 20 godina trajanja braka.

Ovdje donosimo uvid u brojčane podatke za razdoblje od 1970. do 2012. godine. Zaokruživanjem na prosječnih 5000 rastava/razvoda godišnje dobijemo da je riječ o 210000 brakova. Drukčije rečeno, 420000 osoba izravno je pogođeno rastava$\mathrm{ma}$ /razvodima u tom razdoblju od četrdesetak godina. Još jednom napominjemo da taj broj uključuje i one koji su se više puta rastavljali/razvodili. Donosimo prikaz sklopljenih i razvedenih brakova, gdje treba zapaziti podatak da su 1950. godine na tisuću sklopljenih brakova 83 braka bila razvedena, a da je 2012. bilo 278 razvoda na tisuću sklopljenih brakova, uz dodatnu napomenu o godišnjem smanjenju sklapanja brakova za $35 \% !^{6}$ No već sljedeće, 2013. godine imamo 5992 razvoda, odnosno 313 na tisuću sklopljenih! A 2014. broj se sklopljenih brakova nešto povećava, na 19 329, dok razvodi brakova prvi put prelaze šest tisuća, odnosno točno 6546 razvedenih brakova ili 339 na tisuću sklopljenih brakova! Podatak za 2015. godinu glasi: sklopljenih je bilo 19 834, a rastavljenih $6010 .{ }^{8} \mathrm{Za} 2016$. godinu: 20467 sklopljenih, a rastavljenih 7036; a 2017. godine: 20310 sklopljeno, a razvedeno $6265 .^{9}$ U Zagrebu je 2015. godine bilo čak 382 razvedena braka na 1000 sklopljenih, ${ }^{10}$ odnosno ide prema 2,5 .

\section{Djeca zahvaćena rastavom/razvodom}

\subsection{ProsjeČni broj DJECe zahVaĆEne Rastavama /RAZVODIMA RODITELJA}

Ovdje ćemo uzeti kao referentnu godinu 1970., u kojoj je bilo 5333 rastave/razvoda brakova te je istovremeno broj djece koja su tim procesima neposredno pogođena 3888. Taj se broj u 2012. godini u razvedenih 5659 brakova povećao na 5374 djece, a već 2013. imamo 5992 rastave i u njima 5594 djece. $^{11}$

Kad bismo, zaokružujući brojke, htjeli od 1970. do 2013. godine vidjeti koliko je djece pogođeno procesima rastave/razvoda brakova vlastitih roditelja, onda to

\footnotetext{
${ }^{6}$ Dodajemo da je broj sklopljenih brakova u 2013. godini pao na 19 169, a broj razvoda povećao se na 5992, što je na 1000 sklopljenih brakova 313 razvedenih; 2014. godine sklopljeno je 19329, a na tisuću sklopljenih razvedeno je 339 brakova, odnosno 6546! Usp. DRŽAVNI ZAVOD ZA STATISTIKU REPUBLIKE HRVATSKE, Žene i muškarci u Hrvatskoj, Zagreb, 2015., 14.

${ }^{7}$ Usp. DRŽAVNI ZAVOD ZA STATISTIKU REPUBLIKE HRVATSKE, Žene i muškarci u Hrvatskoj 2015., Zagreb, 2015., 14.

${ }^{8}$ Usp. ISTI, Statistički ljetopis Republike Hrvatske, Zagreb, 2016., 136.

${ }^{9}$ Usp. ISTI, Statistički ljetopis Republike Hrvatske, Zagreb, 2018., 113.

${ }^{10}$ Usp. ISTI, Statistički ljetopis Republike Hrvatske, 2016., 136.

${ }^{11}$ Usp. ISTI, Žene i muškarci u Hrvatskoj 2015., 14.
} 
izgleda ovako: oko 186000 djece bilo je uključeno u ta zbivanja. Stoga valja iznova naglašavati da je riječ i o rastavama i razvodima obitelji, a ne samo rastavama i razvodima brakova! To znači da u sva promišljanja i istraživanja treba uvrstiti i djecu. Iz podataka je vidljivo da su djeca u gotovo $85 \%$ slučajeva povjerena majkama na brigu, odgoj i uzdržavanje te školovanje. ${ }^{12}$ Naravno da se ne treba ispustiti iz vida sve manipulacije kad je riječ o ostvarivanju prava jednoga od roditelja, kojemu dijete nije povjereno, a to su u većini slučajeva očevi, na tjedni susret $\mathrm{s}$ djetetom/ djecom.

\subsection{DJECA ROĐENA IZVAN BRAKA}

Pregled broja djece rođene izvan braka 2008. - 2017. godine:

- 2008. $-5260^{13}$

- 2009. -5768

- 2010. -5752

- 2011. -5768

- 2012. $-6444^{14}$

- 2013. -6442

- 2014. -6880

- 2015. -6802

- 2016. -7110

- $2017 .-7274^{15}$.

Ovdje imamo u samo deset godina 63500 djece. To iznosimo zbog toga što mislimo da ta djeca imaju drukčiju sliku i iskustvo braka i obitelji i s njima bi crkveno djelovanje, stječući povjerenje, trebalo otvarati i te teme.

\subsection{DJeCA I RASTAVA I RAZVOD}

\subsubsection{Utjecaj na zdravlje djece i meduljudske odnose}

Teško je dokučiti što sve djeca proživljavaju u procesu rastave/razvoda svojih roditelja, počevši od dugogodišnjih razmirica i nesporazuma, jer do rastave i razvoda ne dolazi u pravilu iznenadno, odjednom. Može se reći da ni za jedan uzrast djece taj

\footnotetext{
${ }^{12}$ Usp. ISTI, Statistički ljetopis Republike Hrvatske, Zagreb, 2013., 5.

${ }^{13}$ Usp. ISTI, Statistički ljetopis Republike Hrvatske, 2010., 111.

${ }^{14}$ Usp. ISTI, Statistički ljetopis Republike Hrvatske, 2012., 120.

${ }^{15}$ Usp. ISTI, Statistički ljetopis Republike Hrvatske, 2018., 116.
} 
proces nije bezazlen i da ih pogađa traumatično, duboko i dugotrajno. Od osjećaja se najčešće spominju ljutnja, žalost, strah, osamljenost, osjećaj grješnosti, bijes, odbacivanje okoline. I mnoge druge osjećaje nose u sebi, s različitim intenzitetom, ovisno o uzrastu, spolu i ostalim oznakama svakoga pojedinoga djeteta. Naravno da je vrlo kompleksno taloženje svih tih osjećaja i promišljanja u ranom djetinjstvu kada dijete postaje uzdrmano jer je ljubav ugrožena; gubitak jednoga od roditelja ne razumije, a tu je i strah da ne izgubi i drugoga roditelja, zbunjeno je svim igrama kojima je izloženo. Prema nekim studijama, takvo je dijete ugroženije u svom rastu i sazrijevanju od druge djece. Pa tako u školi može doći do nazadovanja i određenih teškoća. Posebice u vrijeme puberteta, jer u tom prijelaznom razdoblju mlada osoba treba oslonac, traži svoj identitet, što mu je otežano jer su vrjednote vjernosti, žrtve, odgovornosti za druge poremećene u razrušenom obiteljskom sustavu. Uvlači se i naglašena nesigurnost, koja je inače karakteristična za to razdoblje. Temeljno je, što je i dokazano, da djeca imaju psihičkih problema i da pate od depresije, da postaju agresivna, neka i asocijalna, te da čak pokušavaju samoubojstvo.

Stoga je razumljivo kad jedan mladić, pogođen procesom rastave/razvoda roditelja, kaže: Ni smrt nije tako teška kao rastava, razvod. Psiholozi će reći da dijete čak nekako stabilnije raste kad mu jedan od roditelja umre nego kad se rastanu i razvedu.

\subsubsection{Utjecaj na koncept braka u djece}

Smijemo ustvrditi da se kod djece iz rastavljenih i razvedenih brakova i obitelji stvara pomutnja s obzirom na njihovo shvaćanje braka i obitelji. Međusobna ljubav roditelja davala im je sigurnost u ljubav prema njima, djeci. Spontano očekuju da ta ljubav i brižljivost budu trajni. Poznato je (i pedagoški neopravdano) da djecu pogađa kad ih se u odgojnom procesu uvjetuje: Ako učiniš ovo ili ono, mama ili tata te više ne će voljeti... Sada je, procesom rastave/razvoda, daleko više ugrožena ta ljubav i pomalo nestaje, baš kao i osjećaj sigurnosti, što za posljedicu ima da se u njihovoj nutrini ruši i upravo nestaje bračno-obiteljski sustav. Odnos muškarca i žene u instituciji braka i obitelji više nije jasan. Ako nešto znaju o svojoj kršćanskoj vjeri, onda nastaju bremenita pitanja o vjernosti Bogu, koji traži nerazrješivu ženidbu i stabilnu obitelj.

\subsubsection{Jesu li djeca pogodena rastavom i razvodom roditelja sklonija rastavama $i$ razvodima kasnije, $u$ vlastitom braku?}

U okviru Mannheimer Scheidungsstudie (Mannheimova studija o rastavi) anketirano je 5020 osoba i došlo se do zanimljivih rezultata, među njima se u prvih pet godina braka rastalo $25 \%$ upravo onih kojima je barem jedan roditelj također bio rastavljen/razveden. Istodobno brakovi onih čiji su roditelji imali stabilan brak po- 
kazuju se u $90 \%$ slučajeva stabilnima u tih prvih pet godina. Taj podatak kao da želi reći da su roditelji činjenicu svoje rastave prenijeli na svoju djecu, pa su to nazvali međugeneracijskim prenošenjem rastave/razvoda (intergenerationale Scheidungstransmission). Potrebno je ipak postaviti pitanje: Zašto se češće rastavljaju/razvode djeca čiji su roditelji bili rastavljeni i razvedeni od onih čiji roditelji to nisu bili? I nastaje neki oblik obiteljske kulture. ${ }^{16}$

\section{Posljedice rastave/razvoda za supružnike}

Ukratko iznosimo neke utjecaje rastave/razvoda braka na muškarce i žene koji su dionici toga procesa, bilo da je riječ o dugotrajnijoj neformalnoj zajednici, a pogotovo kad je posrijedi bio pravi brak. ${ }^{17}$ Obično se kaže da su rastava i razvod stres. Ipak, taj se stres bitno razlikuje od onih svagdanjih. Naime ovdje je riječ o zbiru stresova, i to vrlo različitih, koji su se akumulirali prije rastave, ali ostaju i nakon rastave, odnosno razvoda. Prva stresna posljedica jest gubitak afektivnih odnosa u obitelji i lomljenje povezanosti unutar nje. To je intenzivna faza žalovanja, kad subjekti trpe zbog gubitka identiteta jer vlastiti ja trebaju odvojiti od svoga partnera, što često izaziva ljutnju, srdžbu, potištenost, depresiju i smanjenje sigurnosti u sebe, osjećaj grješnosti, osamljenosti, nemoći. $\mathrm{K}$ tomu dolazi i propast zamišljenoga i prihvaćenoga projekta braka, sa svim onim što to znači. Ugroženo je samovrjednovanje vlastite osobe te je narušena slika o sebi u društvenoj dimenziji života. ${ }^{18}$

U rastavi i razvodu gubi se i potpora partnera, nestaje ta zaštitna dimenzija braka. Prestaje prostor dijeljenja suodgovornosti, misli i intimnosti. Izvor su stresa sudski procesi, dodjeljivanje djece, podjela imovine, traženje stana, posla, organizacija ekonomskoga vida življenja...

Rastavom i razvodom pojedinac mora ponovno ustrojiti vlastiti život, što je dodatni i dugotrajni stres. Ukratko: krah nekoga braka događaj je koji pogađa oba partnera na psihološkom i emocionalnom, socijalnom, kulturnom i vjerskom području. On uključuje fazu razgradnje braka - emotivno odlaženje i distanciranje od partnera, legalni proces razvoda, ekonomski i socijalni vidik, roditeljski vidik, kao i u svemu

\footnotetext{
${ }^{16}$ Usp. M. KLEIN, Ist Ehescheidung übertragbar? Kindergeschiedener Eltern lassen sich heutiger scheiden als Kinder, deren Eltern nicht geschieden sind, 2. Dostupno na: http//www.lans-online.de/scheidungstransmission.pdf (5. 4. 2016.).

${ }^{17}$ Služimo se studijom: M. BERGAGLIO, Il divorzio come fonte di malessere, u: Famiglia oggi, br. 4., travanj 2000., 1-12.

${ }^{18}$ Možemo se složiti da je »moralna smrt braka često bolnija i definitivnija negoli sama fizička smrt jednoga bračnoga druga « (J. GRBAC, Rastavljeni i ponovno oženjeni: stanje i perspektive, u: Bogoslovska smotra 85(2015.)3, 779-798., ovdje 792.).
} 
popraćeni psihički aspekt. Treba reći da je takav stres kumulativan i trajnije, iako ne kod svih jednako, utječe na zdravlje sudionika.

Dokazano je da kod mnogih slabi imunitet, oštećuju se kardiovaskularni i endokrini sustavi, nestaje pozitivna kontrola obiteljskoga sustava, pa se javljaju veće nervoze, alkoholizam, druge neurednosti, a time i veća potrošnja lijekova. Naglašeni su dakle neurološki, psihijatrijski i psihološki problemi. ${ }^{19} \mathrm{~K}$ tomu istraživanja u Italiji pokazuju i veću i raniju smrtnost rastavljenih/razvedenih od onih koji to nisu. ${ }^{20}$ Naime iz podataka uočljivo je da su najmanje stope smrtnosti prisutne u svim dobnim skupinama kod osoba u braku. To vrijedi za osobe obaju spolova. Pritom su uobičajeno stope smrtnosti oženjenih muškaraca veće nego udanih žena. Međutim zanimljivo je uočiti da rastavljeni/razvedeni muškarci imaju višestruko veću stopu smrtnosti od žena u istim dobnim skupinama. Npr. u dobi od 20 do 24 godine rastavljeni/razvedeni muškarci umiru 7,5 puta više nego žene. Ovdje treba dodati tvrdnju iz uvoda: »Trauma - rana koju vrijeme ne liječi «.

\section{Nužno je raditi s pojedinom osobom}

Vrijedi poslušati i osjetiti snažan poziv da se zapodjene razgovor sa svima pogođenima, da se s njima hoda poput Isusa na putu u Emaus, da crkveni djelatnici uče umijeće slušanja i praćenja, da budu primjereni, bez agresivnosti i osuđivanja, već $s$ dubokim poštovanjem i suosjećanjem, koje oslobađa i potiče kako svaku obitelj treba prije svega saslušati s poštovanjem i ljubavlju i pratiti vodeći se Isusovim primjerom na susretu s učenicima na putu za Emaus. Za te situacije vrijede na osobit način riječi pape Franje: »Crkva će svoje članove - svećenike, redovnike i vjernike laike - morati uvesti u to 'umijeće praćenja drugoga' kako bi svi naučili izuti svoje sandale pred svetim tlom drugoga (usp. Izl 3,5). Ritam toga praćenja mora biti odmjeren i ohrabrujući, odražavajući našu bliskost i pogled pun poštivanja i suosjećanja, koji ujedno ozdravlja, oslobađa i potiče rast u kršćanskom životu. ${ }^{21}$

\section{Proći proces sučeljavanja sa sobom}

Čini nam se da rastavi i razvodu treba pristupiti analitički, terapijkki, pravno te crkveno integrirajuće.

\footnotetext{
${ }^{19}$ Detaljnije i diferenciranije o bolestima vidjeti: M. BERGAGLIO, Il divorzio come fonte di malessere, 4-6.

${ }^{20}$ Usp. isto, 6-8.

${ }^{21}$ EG, br. 169. AL, br. 300.
} 
Čitajući razgovore, na više smo mjesta vidjeli da su pojedini sudionici više godina muku mučili s prosuđivanjem svoga stanja i svoga udjela u tom mučnom zbivanju rastave/razvoda braka i obitelji. Više njih govori da ne mogu sebi oprostiti. Isto tako mnogi spominju da ne mogu oprostiti bivšem suprugu odnosno supruzi. $\mathrm{Uz}$ to $u$ više drugih studija nailazimo na podatke koji govore o većem oštećenju imuniteta te dosljedno većoj podložnosti obolijevanju i većoj smrtnosti osoba koje su proživjele proces rastave/razvoda. Stoga mislimo da je važno takvim pojedincima ponuditi određeni proces razmišljanja i vježbanja kako bi prosudili svoje stanje, svoj dio krivnje, krivnje drugoga, da uopće odgovore na pitanja uzroka, ali i posljedica, da se strukturiraju za novi život i opredijele za njegovu kvalitetu, tj. da žive tjelesno i duševno zdravo, i to najviše moguće. I sama Treća izvanredna biskupska sinoda govori o tome da trebaju za taj proces postojati čak i posebni centri u biskupijama. »Otud nužnost pastorala pomirenja i posredovanja također uz pomoć prihvatilišnih centara koje treba osnivati u biskupijama. ${ }^{22}$ Naravno da se očekuje da ti centri budu kvalitetni i vrhunske profesionalnosti i duhovnosti. Isto naglašava i završni dokument Sinode 2015. godine kad kaže da oproštenje za podnesene nepravde nije lagano, ali je put koji mogućim čini milost. Zato je potreban pastoral obraćenja i pomirenja koji bi trebali voditi posebno specijalizirani centri za slušanje i posredovanje ustanovljeni u biskupijama. Poznat je termin medijacija (posredovanje). Takvi centri trebaju imati specijaliste za to područje i treba proći podosta vremena da se za njih čuje i da budu uspješna pomoć onima u potrebi.

U tim centrima trebalo bi se ujedno ostvarivati asistiranje ili pastoralno praćenje onih koji su doživjeli proces rastave/razvoda. Cilj bi trebao biti da se postigne jasnoća sa samim sobom i da dođe do oproštenja. »Posebno razlučivanje je nužno za pastoralno praćenje razvedenih, rastavljenih i ostavljenih. Treba prije svega vrednovati patnju onih koji su nepravedno pretrpjeli rastavu ili razvod, rastavu ili ih je bračni drug napustio, ili su zbog zlostavljanja kojima su bili izloženi od strane bračnog druga bili prisiljeni prekinuti zajednički život. Oprostiti pretrpljenu nepravdu nije lako, ali je to hod kojeg omogućuje milost.« Isto govori i završni dokument AL, br. 242: »Oprostiti pretrpljenu nepravdu nije lako, ali je to hod koji omogućuje milost. Otud nužnost pastorala pomirenja i posredovanja također s pomoću prihvatilišnih centara koje treba osnivati u biskupijama.«

\section{Proces i etape opraštanja}

Na tragu potreba opraštanja sebi i drugima, tražeći potrebne instrumentarije, ustanovili smo određenu oskudnost u literaturi, a pogotovo je malo predloženih mo-

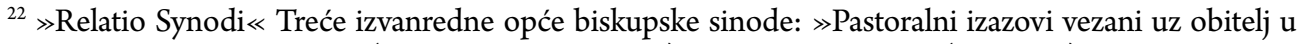
kontekstu evangelizacije « (5. - 19. listopada 2014.), 18. 10.2014., br. 47 (podv. PA); usp. AL, br. 242. 
dela za taj specifičan rad s rastavljenima/razvedenima, razvedenima i ponovno civilno vjenčanima, napose kroz vidik opraštanja. Stoga je dragocjena studija Jeana Monbourqettea Kako oprostiti. Oprostiti da se ozdravi, ozdraviti da se oprosti (67195. ${ }^{23}$, iz koje ćemo uzeti predloženih 12 etapa, koje su doista interdisciplinarno utemeljene i može ih se dobro upotrijebiti za pojedinačni ili skupni proces. Posebno se doima isprepletenost, kako rekosmo, interdisciplinarnih činjenica i biblijskih poruka, tako da je proces prihvatljiv ponajprije za sve denominacije kršćana. Posebnu pozornost treba posvetiti vježbama koje svakoga pojedinoga upravljaju prema samoanalizi, samospoznaji, samoprosudbi i osobnoj odluci. Stoga je jasno da taj proces treba voditi stručna osoba, visoke ljudske i vjerničke istančanosti i duhovnosti. ${ }^{24}$

Gledajući sve što se treba proći, opravdano autor taj hod naziva etapama, tj. kao naznačeni put, a brzinu u pojedinim etapama hoda odredit će pojedini sudionik, jer će neke dionice puta tražiti manje, a druge više vremena.

Autor naglašava da je važno voditi i dnevnik te imati potrebna sredstva za izvršavanje vježbi.

Sam pojam opraštanja izaziva različito shvaćanje s jedne strane, a s druge uz sebe povezuje bezbrojne emocije svega proživljenoga ili još uvijek proživljavanoga. Zato nam se čini opravdano reći da treba razlikovati oproštenje koje može prethoditi i biti samostalno i odvojeno, npr. onima fizički daleko ili već pokojnima, od pomirenja koje po sebi nije odmah nužno, a više puta je i nemoguće s obzirom na drugu stranu, koja može biti okorjela.

Opraštanje je kompleksan proces i stoga neke moguće nesporazume i odbijanja treba također predusresti. Naime opraštati ne znači zaboraviti, jer je nemoguće, a i nepotrebno je tražiti ili očekivati da se zaboravi. ${ }^{25}$

\footnotetext{
${ }^{23} \mathrm{~J}$. MONBOURQETTE, Kako oprostiti. Oprostiti da se ozdravi, ozdraviti da se oprosti, Zagreb, 2002., 3.

${ }^{24}$ Jedna druga studija od dvoje autora J. MONBOURQETTE, I. D’ASPREMONT, Tražiti oproštenje a ne poniziti se, Zagreb, 2014., obrađuje također temu opraštanja, što znači da je ona vrlo aktualna na svim područjima, a ne samo kad su u pitanju rastavljeni i razvedeni. Prva studija bliža je upravo rastavljenima/razvedenima. U drugoj navedenoj studiji (43-118.) predlaže se 9 etapa na putu opraštanja: 1) Probuditi svoju moralnu odgovornost; 2) Priznati svoja duševna stanja, raspoznavati ih da biste njima dobro upravljali; 3 ) 'Kajanje bića' i reintegracija svojih sjena; 4) Oprostiti samima sebi jer smo dostojni oproštenja; 5) Što je sa skrivenom krivnjom, nepoznatom povrijeđenomu? 6) Priznata krivnja već je napola oproštena; 7) Tražiti oproštenje; 8) Oproštenje, pomirenje, odbijanje oproštenja; 9) Slaviti svoje oproštenje a ne poniziti se. U svim etapama, osim promišljanja teološke, moralne i psihološke naravi, donose se i vrlo korisne vježbe koje treba učiniti da bi se napredovalo u procesu opraštanja.

${ }^{25}$ To su sažetci razmišljanja Jeana MONBOURQETTEA, Kako oprostiti, 24-36.
} 
»Pravo opraštanje od srca ostvaruje se u poniznosti i otvara put istinskom pomirenju. Lažno opraštanje, naprotiv, samo zadržava odnos onoga koji vlada i onoga nad kojim se vlada. ${ }^{26}$ Opraštanje nije prebacivanje odgovornosti na Boga kao što to mnogi od nas rade govoreći neka mu Bog oprosti. Sve emocije valja obrađivati i doprinositi vlastitom mentalnom zdravlju. Na kraju, oprostiti ne znači da će biti kao prije uvrjede. Slikovito autor to kaže ovako:

$\gg$ Ali pogrešno je misliti da je, jedanput davši oproštenje, moguće naći se sa svojim uvrediteljem kao prije. Nakon što se napravi omlet, mogu li se vratiti jaja? Nakon što se ispeče kruh, može li se povratiti brašno? Nije moguće vratiti se natrag nakon što se podnijela nepravda. Ili se pak pokušavamo uvjeriti da se ništa nije dogodilo i tada uspostavljamo odnos u laži ili se pak sukobom koristimo da provjerimo kakvoću odnosa i da odnos prebacimo na nove, čvršće temelje. $\ll^{27}$

Valja ustvrditi da oproštenje nije trenutačan čin, već ono obuhvaća ono prije, za vrijeme i poslije, tj. to je opraštanje koje je proces, koje traje. Iz svega slijedi da >čin opraštanja traži, dakle, niz posve jednako važnih uvjeta: vrijeme, strpljivost sa samim sobom, sposobnost održavanja želje za uspjehom, ustrajnost u odluci da se ide do kraja. Zato, kad pokušavam naći najprimjerenije izraze da ga opišem, na um mi dolaze 'unutarnje obraćenje', 'hodočašće srca', 'uvođenje u ljubav prema neprijateljima,' 'traženje unutarnje slobode'. Svi ti izrazi odražavaju nužnost hoda. $\ll^{28}$

\section{Etape procesa opraštanja od 1. do 12. koraka}

Naš autor predlaže i donosi 12 etapa. Mi ćemo sažeti sadržaje pojedinih etapa potkrijepljeno iskazima naših sugovornika i donijeti većinu prijedloga za vježbe, što nam se čini važnim. Zato treba uzeti vrijeme, ostvariti potrebne uvjete i ozbiljno sebi odgovarati na postavljena pitanja i pokušavati doći do što bolje jasnoće. Ponovimo: dobro je i zapisivati. Sve će se obogatiti i biblijskim citatima ili zgodama, koje mogu pomoći i biti vodič. Ovdje se ne smije ispustiti iz vida i molitveni vidik svake etape i svih vježbi, što se prepušta i voditelju i sudioniku/ ci toga procesa.

\footnotetext{
${ }^{26}$ Isto, 34., opširnije o temi vidjeti: W. KASPER, Milosrđe. Temeljni pojam evanđelja - ključ kršćanskoga života, Zagreb, 2015., 178-183., posebno 178-179.

${ }^{27} \mathrm{~J}$. MONBOURQETTE, Kako oprostiti, 31.

${ }^{28}$ Isto, 39.
} 


\subsection{Ne OSVETITI SE I ZAUSTAVITI NAPADAČKE ČINI}

U našim razgovorima nailazili smo na primjere osvećivanja i progona. Tako smo dobili slične iskaze: $\gg$ On je prijetio i da će me ubiti i odležati. Odazivao se samo kad je morao. Sud je donio brzo odluku a onda je on počeo prijetiti... $\ll{ }^{29} \mathrm{U}$ ovom hodu prema opraštanju traže se na samom početku dvije važne odluke: prvo, da se odrekne od osvećivanja i, drugo, da se zaustave napadanja bilo koje vrste i strane. Što to znači osvećivati se? A kako zaustaviti drugoga u napadanju?

\subsection{Priznati SVOJu POVRIJEĐENOST I SIROMAŠTVo}

Jedna od naših sugovornica svoju životnu etapu želi izbaciti iz života i zato izgovara radikalne stavove. »Ne volim ga ni spominjati, niti ga se sjećati. To razdoblje svoga života jednostavno sam izbacila iz svog života. On za mene ne postoji. Srećom ne živimo više u istom gradu tako ne postoji ni mogućnost da se više sretnemo. ${ }^{30}$ Naravno da se nameću mnoga pitanja kao što su: Može li se sve staviti u zaborav? Može li se nekoga proglasiti mrtvim? Ne treba li upravo obratno obraditi sve uvrjede i osjećaje, u duhu se susresti sa svime što nam je spomenuti učinio? Ova etapa traži upravo oživljavanje događaja uvrjede da bi se naučilo prihvatiti nanesenu bol, njegovati ju i preobražavati. Riječ je o povratku samomu sebi. Ali »nikad nećeš uspjeti oprostiti ako ustraješ u nijekanju da si bio povrijeđen i ranjen i da je, istodobno, tvoje nutarnje siromaštvo razgoljeno. ${ }^{31}$ Vjerojatno bi to bilo i nešto lakše da nije naših usađenih obrambenih mehanizama, kojih valja postati svjesniji. Naime obrambeni mehanizmi po sebi su pozitivni. Pomažu pogođenoj osobi da preživi, da ne bude potpuno shrvana.

\subsection{Podijeliti s NeKim SVOJu POVRIJEĐenost}

Odmah se nameće pitanje je li potrebno i važno da se s nekim podijeli vlastita uvrijeđenost. Odgovor je pozitivan, jer u protivnom postoji opasnost da se osoba zatvori i počne igrati ulogu žrtve. Put izlječenju jest da se nekom sve povjeri, nekom tko će saslušati, ne će obilno savjetovati, pogotovo ne će osuđivati. Dakle posebnu važnost u procesu opraštanja ima upravo osoba pažljivoga sugovornika. Tako nešto govori i naša sugovornica kad kaže: »Ne toliko konkretnu pomoć, iako je to ponekad jako potrebno. Više očekujem razumijevanje, spremnost na slušanje, a nikako ne na osuđivanje. $\ll^{32}$ Treba pobliže promotriti razlog komuniciranja uvrijeđenosti.

\footnotetext{
${ }^{29}$ Usp. razgovor br. 3 studije P. ARAČIĆ, Trauma rastave i razvoda braka i obitelji, 230-233., ovdje 231.

${ }^{30}$ Razgovor br. 14 iz isto, 299-306.

${ }^{31}$ J. MONBOURQETTE, Kako oprostiti, 78.

${ }^{32}$ P. ARAČIĆ, Trauma rastave i razvoda braka i obitelji, 28.
} 


\subsection{Dobro IDENTIFICIRATI SVOJ GUbitAK I ObAViti ŽAlOVANJE}

Svatko od nas ima potrebu, ali i obvezu dobro promotriti svoju povrijeđenost, a onda i gubitak da bi mogao biti bliže istini o tom svom gubitku. Tek tada će moći ići putem oproštenja. Naime u opasnosti smo da kažemo da je u pitanju sve, cijela moja osoba kao takva. Međutim istina je upravo u tome da se najčešće pogađa neki dio mene, neko moje iskustvo, nešto iz ranoga djetinjstva, nešto polusvjesno i sl. Tako stav da je nešto potpuno, jedino i trajno po sebi jest radikalan pristup i rijetko istinit. Gotovo je uvijek riječ o dijelovima udjela i drugih, naravno, i mene, a ne da sam svemu kriv samo ja! Dobro je popisati svoje gubitke. I u braku i u obitelji!

\subsection{Prihvatiti SRDŽBu I ŽELJU Za OSVETOM}

Svatko od nas ima trenutaka ljutnje i poriva za osvetom uvrjeditelju. To su normalne reakcije. Opasne su kada prelaze u zlopamćenje te iz toga, kao iz gnjiloga ozračja, zagađuju međuljudske odnose. Stoga »ne priznati i ne prihvatiti svoju srdžbu i svoju želju za osvetom pod izlikom da se želi oprostiti znači lagati samomu sebi i još uz to preobući oproštenje u jedan oblik društvenog pretvaranja. $\ll^{33}$

\subsection{OPROSTITI SAMOMU SEBI}

Postoje i neki izvori naših neprijateljstava prema samomu sebi. Prvi je što maštamo o apsolutno čistoj sreći i savršenom biću, i to bez granica i mana. Valja učiti svoju grješnost i ograničenost. To dovodi do krjeposti poniznosti. Drugi izvor okrivljivanja samoga sebe jesu negativne poruke od bliskih i voljenih osoba, npr. kad se djeci prilijepe uvrjedljive riječi, nadimci, zapušta ih se... i sve se te uvrjedljive poruke skupljaju i dovedu do osjećaja manje vrijednosti, pa čak i depresije te mogućega pokušaja ili i čina samoubojstva kao krajnjega oblika odbijanja oproštenja samomu sebi. Treći pak izvor osjećaja krivnje i odbijanja oproštenja sebi izvire iz sjena prošlosti onih dijelova osobnosti koje se nisu mogle razviti u određenoj društvenoj sredini, jer ih je smatrala neprihvatljivim.

Carl Jung govori vrlo zanimljivo, ali i uvjerljivo, o ljubavi prema sebi: »Prihvaćanje sama sebe bit je moralnoga problema i sažetak svega viđenja života. Ako dadem jesti onima koji su gladni, ako oprostim uvredu, ako ljubim svoga neprijatelja u Kristovo ime, to, bez ikakve dvojbe, sačinjava velike kreposti. Što učinim jednomu od svoje najmanje braće, Kristu to činim. Ali što bih učinio kad bih otkrio da se najmanji od svih onih koji su me uvrijedili nalazi u meni, da sam ja taj koji ima potrebu

${ }^{33}$ Isto, 107. 
milostinje moje ljubaznosti, da sam ja neprijatelj koji traži moju ljubav? $\ll^{34}$ Svatko osjeća kako je to zahtjevno i kako to i nadilazi naše moći. No čovjek se nalazi i u obzorju blagoga Božjega milosrła, te stoga nije prepušten samomu sebi i zato mu nije dopušteno upadati u mržnju i preziranje sebe.

\subsection{ShVATiti SVOGa UVRJEDITELJA}

U ovom koraku pretpostavlja se da smo se riješili one prevelike zabrinutosti oko same povrjede koju smo doživjeli i da smo sposobni ići dalje izlazeći iz sebe te pogledati i onoga koji nam je učinio zlo, povrijedio nas, uništio brak ... Valja reći da taj pokušaj da pogledamo i u drugoga ne znači da ga želimo opravdati ili osloboditi krivnje, već je riječ o tome da pokušamo jasnije dohvatiti dimenzije njegove osobnosti i motive za počinjeno. Vjerujemo da bismo tim postupkom opraštanje mogli doživjeti ponešto lakšim i ono ne bi bilo tek neki površni čin. Istovremeno bi se i slika o počinitelju ponešto mijenjala. Dakle ne čin zatvorenih, već široko otvorenih očiju! Zato: Prestati osuđivati. Svatko ima svoju povijest te i uvrjeditelj ima svoju vrijednost i dostojanstvo. Zato ponekad valja prihvatiti da ne razumijemo sve.

\subsection{NAĆI U SVOM ŽIVOTU SMISAO POVRJEDE}

Učinili smo do sada dosta etapa na tom putu: odluka da se ne želimo osvećivati, da se želimo vratiti sebi, uvidjeti unutarnju patnju i nju prihvatiti te razvijati raspoloženja shvaćanja uvrjeditelja. Temelji i psihološki preduvjeti za oproštenje ovdje su. Sada valja vidjeti što učiniti od te nepravde, od uvrjede, od izdaje, nevjernosti. Kako unatoč svemu rasti? Put koji se traži jest da otkrijemo moguće pozitivne učinke koje je uvrjeda proizvela ili može proizvesti. Kako dakle neuspjeh u braku i obitelji okrenuti u prednost? Valja početi vjerovati da doživljena povrjeda može postati izvorom rasta, sazrijevanja. Doista, $\gg$ izazov $(. .$.$) je ponovno spojiti fine niti$ slomljena života da bi se od njega učinilo djelo bogato smislom i odgovornošću «. ${ }^{35}$

Htjeli ili ne htjeli, često tek kad nas nešto udari počnemo dublje razmišljati i dosljednije živjeti. Tu imamo tri razdoblja. U prvom razdoblju nastaju pitanja žalovanja s obzirom na ono što se događalo i dogodilo. U drugom razdoblju posvećujemo se upoznavanju sebe i svojih planova za budućnost. Treće razdoblje jest uređenje svoga života. Ta razdoblja ne treba prolaziti brzo i preskačući. No, ipak, posebno vrijeme i dubinu promišljanja treba pokloniti u drugom razdoblju. U njemu bismo si trebali postaviti prvo pitanje: Kako sam dospio u takvo stanje ranjivosti? Rane koje su nastale povrjedom ili povrjedama dovode nas do rješavanja nekih iluzija

\footnotetext{
${ }^{34}$ C. JUNG, L'homme à la recherche de son âme, Linn, 1987., 84., cit. prema: J. MONBOURQETTE, Kako oprostiti, 128.

${ }^{35}$ G. ALLPORT, cit. prema: J. MONBOURQETTE, Kako oprostiti, 146.
} 
o sebi i o drugima, kao i uloga i stajališta, i svojih i drugih. Nastaje i drugo pitanje: Tko sam zapravo ja? I nitko na to pitanje ne može odgovoriti doli ja sam. Za to mi treba mira i temeljitoga promišljanja. Bit će prisutni tjeskoba i strah te osamljenost. Isto tako u ovom razdoblju valjat će postaviti i treće pitanje: Što želim učiniti od svoga života? Razlozi življenja?

U svem procesu valja naći smisao vlastite patnje. Viktor Frankl, patnik u koncentracijskom logoru, u knjizi Nečujni vapaj za smislom kaže: »Važno je dakle prizvati se na najviše čovjekove mogućosti, mogućnosti da osobnu tragediju preobrazi u pobjedu, patnju u ljudsko ostvarenje. $\ll^{36}$

\subsection{Dostojan SAM OPRoŠTenJa I VeĆ MI Je OPROŠTENO}

Tijekom ovih etapa češće smo osjećali i svoje granice. Naprezali smo se, ali i dolazili do naslućivanja da je oproštenje s jedne strane čovjekovo nastojanje, a s druge Božji milosni dar. I sada je na redu upravo dublja duhovna sfera. »U trenutku kada tvoj postupak opraštanja ulazi u oblast duhovnoga, smanjuje se tvoja inicijativa i tvoja moć, a tvoje nastojanje sastoji se više u tome da se opustiš i prepustiš da te prožme milost. $\ll^{37}$

Četiri su skupine osoba koje imaju velikih teškoća vjerovati da su voljeni i uključeni u opraštanje. Jedni su oni koji misle da su im grijesi tako veliki da im se ne može oprostiti. Takvih je u modernom svijetu sve manje. Drugi su oni koji ne vjeruju u besplatnost ljubavi, pa time i oproštenja, jer će, po njima, sve biti ovako ili onako naplaćeno. Treći su oni koji odbijaju oproštenje jer, živeći u duhovnoj praznini, nemaju osjećaj ni osobne pojedinačne ni društvene krivnje. Napokon, četvrti odbijaju osjećaj krivnje govoreći da je riječ o psihološki upitnim stanjima. Treba razlikovati bolesne osjećaje krivnje od zdravih i normalnih, koji upozoravaju da je čovjek ograničeno i slabo biće i da mu je potrebno oslobađanje da bi mogao postizati moralni ideal u življenju.

\subsection{Prestati htJeti Oprostiti pod SVAKu CiJenu}

Ovaj naslov, ali i korak, prestati htjeti oprostiti pod svaku cijenu, svakako je iznenađujući i provokativan. Toliko uloženoga truda stavlja se u pitanje. Ali upravo je to pitanje ključno i ujedno vrlo izazovno za osobnu iskrenost: kako se osloboditi $\gg$ podmukle oholosti i svakog instinkta prevlasti koje bi pokušao tražiti hoteći oprostiti

\footnotetext{
${ }^{36}$ V. FRANKL, Nečujni vapaj za smislom, Montreal, 1988., 121., cit. prema: J. MONBOURQETTE, Kako oprostiti, 152.

${ }^{37}$ J. MONBOURQETTE, Kako oprostiti, 154.
} 
pod svaku cijenu. ${ }^{38}$ Riječ je naime o tome da se pokušava opraštati uzdajući se u svoje sile. Valja se odreći toga da sam ja sam i jedini činitelj opraštanja. I opasnosti da mi to bude sredstvo prevlasti, nadmoći! U tijeku ovoga procesa valja sačuvati dobru mjeru osobnoga napora, ali istodobno potpunu svijest i otvorenost da jedini Bog i njegovo milosrđe izvode opraštanje. Ono je dar kojemu treba biti otvoren i primiti ga i darovati dalje. Tako oproštenje i opraštanje postaje životni stil, a ne tek nekakav moralni propis. Tako se da naslutiti iz scene kad je Petar pitao Isusa koliko puta treba oprostiti nekomu tko se o njega ogriješi, kad je njegov odgovor bio: $\gg \mathrm{Ne}$ kažem ti do sedam puta, nego do sedamdeset puta sedam.«(Mt 18, 21-22) $)^{39} \mathrm{Ne}-$ brojeno puta, zapravo, riječ je o stalnom opraštanju kao stilu življenja.

\subsection{OTVORITI SE MILOSTI OPROŠTENJA}

Oprostiti znači odazvati se Isusovu pozivu: »Budite milosrdni kao što je Otac vaš milosrdan.«(Lk 6, 36) No skanjivanje i dalje postoji i teškoća unatoč pozitivnom htijenju. Kako to? Vjerojatno bi trebalo pročistiti naše slike o Bogu.

Svaki od nas opterećen je različitim poimanjem Boga, već prema tomu kako su nam ga predstavljali naši najbliži počevši od roditelja, svećenika, vjeroučitelja, bliskih i važnih osoba u našem životu i odrastanju. Nažalost, valja istaknuti da je za neke od njih Bog bio u funkciji discipliniranja, prijetnji, kažnjavanja, zastrašivanja, policajca koji sve prati, profesora koji sve najmanje nejasnoće ispravlja... Ponajčešća slika koja nam je prenesena jest ona Boga kao strogoga sudca, koji neumoljivo kažnjava. Zato kod mnogih kršćana treba poduzeti put čišćenja tih slika iz nas, jer u protivnom ostajemo nesposobni opraštati.

\subsection{ODLUČITI OKONČATI ILI OBNOVITI ODNOS}

Dogodilo se oproštenje uvrjeditelju s jedne strane. Nastaje važno pitanje: Što s odnosom tih dviju osoba, prekinuti ili obnoviti i produbiti?

Mnogi će teoretičari i praktičari reći da su oproštenje i pomirenje nerazdvojno povezani i nerazdruživi. I da oproštenje nije potpuno bez pomirenja. Kao da se misli da oprostiti znači sve zaboraviti kao da se nije ništa ni dogodilo te da odnos supružnika može odmah biti kao da se ništa nije ni dogodilo. Vjerojatno to mnoge priječi da priđu procesu oproštenja, jer im se, tako misleći, čini da bi to bilo prividno opraštanje.

Zasigurno da bi bio poželjan slijed oproštenje, pa i pomirenje. Pogotovo za one osobe iz tijesnih povezanosti kao što su bračni drugovi, djeca i roditelji, prijatelji,

\footnotetext{
${ }^{38}$ Isto, 163.

${ }^{39}$ Usp. isto, 163-167.
} 
susjedi, sudrugovi na poslu. Kad bi pomirenje i bilo moguće, to ne znači ponovni odnos kakav je bio prije. On više ne postoji. Morao bi se stvarati novi odnos koji će biti dublji ili posve novi. ${ }^{40}$

\section{Integracija u zajednicu}

Ovdje donosimo neke ideje i prijedloge koji mogu pomoći da se uopće pokrene to veliko i pastoralno zapušteno područje:

\section{1) imati pregled u zajednici i susresti se s njima}

Ovdje je riječ o tome da svaka zajednica vjernika vidi koliko ima rastavljenih, razvedenih, samohranih nakon razvoda, u drugom braku. Treba pronaći način i osobno se susresti sa spomenutim osobama i uspostaviti razgovor, upoznati se, pokušati steći povjerenje.

\section{2) predložiti spomenuti proces suočavanja i prosudbe}

Ako se dogode pojedinačni susreti, odmah ćemo uvidjeti potrebu što detaljnije analize i prosudbe stanja pojedine osobe u svim procesima koje je prošla i koje prolazi. Stoga bi bilo poželjno predložiti jedan takav proces, i to osobni.

\section{3) pomagati crkveno-pravnim uputama}

$S$ pravnim rješenjima ne treba brzati. Nakon prijeđenoga procesa prosudbe može se neke, koji bi mogli imati preduvjete, poslati crkvenim sudcima na razgovor. Svakako se treba suzdržati od prethodnih obećanja i davanja obećanja. ${ }^{41}$

\section{4) u zajednici stvarati ozračje prihvaćanja}

U zajednici treba stvoriti ozračje prihvaćanja pogođenih osoba, a ne osuđivanja. Sud treba prepustiti Bogu. Omogućiti sudjelovanje u svim strukturama života zajednice, o čemu govori i AL, br. 297. i 299. Traži se ublažavanje postojećih propisa!

\footnotetext{
40 \Kada ženidbeni drugovi dožive probleme u svojim odnosima, moraju moći računati na pomoć i praćenje Crkve. Pastoral ljubavi i milosrda stremi k obnovi osobâ $i$ odnosâ. Iskustvo pokazuje da se uz prikladnu pomoć i djelovanjem milosti pomirenja veliki postotak bračnih kriza prevladava na zadovoljavajući način. Znati oprostiti i osjetiti da nam je oprošteno je temeljno iskustvo u obiteljskom životu. Opraštanje među ženidbenim drugovima omogućuje iskusiti ljubav koja je zauvijek i nikada ne prolazi (usp. 1 Kor 13, 8). Međutim, onome koji je primio Božje oproštenje ponekad je teško smoći snage da pruži istinsko oproštenje koje preporađa osobu.« [»Relatio Synodi « Treće izvanredne opće biskupske sinode: »Pastoralni izazovi vezani uz obitelj u kontekstu evangelizacije $\ll$ (5. - 19. listopada 2014.), 18. 10.2014., br. 44 (podv. PA).]

${ }^{41}$ Opširnije vidjeti: J. ŠALKOVIĆ, L. BOLJAT, Priručnik za provedbu pastoralne istrage i pripremu parnice proglašenja ništavosti ženidbe, Zagreb, 2016.
} 


\section{5) formirati osobe za razgovor}

Svaka zajednica trebala bi dodatno formirati nekoliko osoba koje bi mogle ostvarivati prve kontakte, ohrabrivati da se pođe putem suočavanja i nađe mir.

Posebno bi župnici morali proći dodatnu formaciju i vježbe da bi mogli biti stvarni sugovornici i pogotovo za onaj razgovor in foro interno. ${ }^{42}$

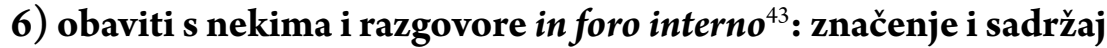

Razgovor sa svećenikom in foro interno mora rastavljenima i civilno vjenčanima pomoći u stvaranju pravilnih sudova o zaprjekama punoga zajedništva s Crkvom. Pri razgovoru svećenika i rastavljene civilno vjenčane osobe svećenik je dužan osvijestiti i analizirati njezino: ophođenje s djecom; nastojanje oko pomirenja; odnos s bračnim drugom s kojim je veza prekinuta; posljedice za ostatak obitelji; posljedice za zajednicu vjernika; upitan primjer mladima koji se pripremaju na ženidbu. ${ }^{44}$

Osobni razgovori s rastavljenima i civilno vjenčanima te svećenikovo praćenje mora omogućiti pravilan sud o poteškoćama i zaprjekama punoga sudjelovanja u životu Crkve te stvarati pozitivne korake, koji moraju pogodovati, omogućavati i pospješiti pastoralno djelovanje pastorala rastavljenih i civilno vjenčanih. ${ }^{45}$ Pravilan sud dogodit će se ako se ostvari kvalitetni personalizirani pastoral koji zahtijeva susret, slušanje, dijalog, poosobljenu formaciju ispravne savjesti i integraciju slabosti.

\section{7) poraditi na predloženim centrima ${ }^{46}$}

O tome što bi trebali sve uključivati ti centri nije detaljno i jasno rečeno. No čini se da su potrebni, jer svi ti procesi traže kompetentne osobe, vrijeme i prostore. $\mathrm{K}$ tomu uvijek valja imati na umu da se traži pastoralno praćenje, drugim riječima, da se računa na moguće nove komplikacije.

\section{8) integrirati u aktivnosti zajednice ${ }^{47}$}

»Oni su kršteni, naša braća i sestre, te Duh Sveti na njih izlijeva darove i karizme na dobro svih. Njihovo sudjelovanje može doći do izražaja u različitim crkvenim službama: stoga je potrebno razabrati koji se od raznih oblika isključenja, koji su

\footnotetext{
${ }^{42}$ P. ARAČIĆ, I. DŽINIĆ, Poželjni sugovornici u životnim pitanjima i teškoćama, u: A. ČOVO, D. MIHALJ (ur.), Muško i žensko - stvori ih. Žene i muškarci u življenju i u službi Božjeg poslanja, Zbornik radova, Split, 2008., 217-241.

${ }^{43}$ Usp. AL, br. 300.

${ }^{44}$ Usp. isto.

${ }^{45}$ Usp. isto.

${ }^{46}$ Usp. isto, br. 242.

${ }^{47}$ Isto, br. 299.
} 
sad na snazi u liturgijskom, pastoralnom, obrazovnom i institucionalnom okviru, mogu prevladati.«

\section{9) pastoralno praćenje}

Papa Franjo kaže: »Crkva će svoje članove - svećenike, redovnike i vjernike laike - morati uvesti u to 'umijeće praćenja drugoga' kako bi svi naučili izuti svoje sandale pred svetim tlom drugoga (usp. Izl 3,5). Ritam toga praćenja mora biti odmjeren i ohrabrujući, odražavajući našu bliskost i pogled pun poštivanja i suosjećanja, koji ujedno ozdravlja, oslobađa i potiče rast u kršćanskom životu. $\ll^{48}$

\section{Zaključak}

Papa Franjo poziva Crkvu i crkvene zajednice da budu na bojnom polju svagdanjega života i naprave bolničke šatore, ${ }^{49}$ jer su joj mnogi izranjeni u svakom smislu, pa su potrebni: medicinari, specijalisti, pomoćno osoblje, jer svaki treći brak puta dvije osobe i barem jedno dijete... ranjeni su, i to traumom, koju vrijeme ne liječi! Tkivo naroda i tkivo Crkve postalo je bolesno! Jesmo li senzibilizirani? Koliko poznamo i pratimo situaciju? »Posebno razlučivanje je nužno za pastoralno praćenje razvedenih, rastavljenih i ostavljenih. Treba prije svega vrednovati patnju onih koji su nepravedno pretrpjeli rastavu ili razvod, rastavu ili ih je bračni drug napustio, ili su zbog zlostavljanja kojima su bili izloženi od strane bračnog druga bili prisiljeni prekinuti zajednički život. Oprostiti pretrpljenu nepravdu nije lako, ali je to hod kojeg omogućuje milost. ${ }^{50} \mathrm{Da}$ bi sve to bilo moguće, poziva nas se na »nužnost pastorala pomirenja i posredovanja također uz pomoć prihvatilišnih centara koje treba osnivati u biskupijama. ${ }^{51}$ Poznat je termin medijacija (posredovanje) i takvi centri trebaju imati specijaliste za to područje i treba proći podosta vremena da se za njih čuje i da budu uspješna pomoć onima u potrebi.

Tako bi se moglo naslutiti da se ostvaruje san kako »Crkva mora brižno i pažljivo pratiti svoju najslabiju djecu, obilježenu izgubljenom i ranjenom ljubavlju, vraćajući povjerenje i nadu ... $\ll^{52}$. »Crkva nije na svijetu da osuđuje, nego da omogući susret s onom dubokom ljubavlju koja je Božje milosrđe. Da bi se to dogodilo, često ponavljam, potrebno je izići. Izići iz crkava i iz župa, izići i ići potražiti osobe tamo gdje žive, gdje pate, gdje se nadaju. Odlika poljske bolnice, a to je slika kojom rado opisujem tu 'Crkvu na izlasku', jest da se ona podiže na bojišnici: ona nije čvrsta

\footnotetext{
${ }^{48}$ EG, br. 169.; AL, br. 300.

${ }^{49}$ Usp. AL, br. 291.

${ }^{50}$ Isto, br. 242.

${ }^{51}$ Isto.

${ }^{52}$ Isto, br. 291.
} 
građevina sa svime opremljena i gdje se odlazi na liječenje lakših i težih oboljenja. To je pokretno zdanje, za prvu pomoć, za hitne intervencije, kako bi se spriječilo da vojnici umru. Tu se primjenjuju hitni medicinski zahvati, a ne rade se specijalistički nalazi. ${ }^{53} \mathrm{~A} u$ istom razgovoru s Torniellijem papa Franjo kaže da upravo danas čovjek treba uho i aktivno slušanje. To naziva apostolatom uha. ${ }^{54}$

${ }^{53}$ FRANJO, Božje je ime Milosrde. Razgovor s Andreom Torniellijem, Split, 2016., 67-68.

${ }^{54}$ Usp. isto, 32. 


\title{
RECOGNIZE, ACCOMPANY, AND TREAT THE WEAKEST IN THE COMMUNITY ACCORDING TO AMORIS LAETITIA
}

\author{
Pero ARAČIĆ*
}

Summary: The paper presents the factual situation of the scourge of separation and divorce in Croatia and, based on the interviews published in a study on these processes, deals in a special way with their impact on the spouses and especially the children from such broken marriages and families. There is also research on the transmission of the culture of separation and divorce to the next generations. Together with Amoris laetitia, the paper discusses what to do and asks the community to help this huge number of traumatized people through the processes of forgiveness and reconciliation, as well as their integration into communities and to be close to them and helpful with great solidarity. Of course, available are also the Church's professional legal services with which an analysis should be conducted of the marital and family situations and see what the Church legislation recommends. In all these processes, which are often lengthy, they are supported by religious closeness and solidarity of the faithful.

Keywords: separations and divorces, children from such marriages and families, experiences of all affected, the path of forgiveness, forgiveness and reconciliation, church integration.

* Full Prof. Pero Aračić, Ph. D., Catholic Faculty of Theology in Đakovo, J. J. Strossmayer University of Osijek, Petra Preradovića 17, P. O. box 54, 31400 Đakovo, Croatia, pero.aracic@os.t-com.hr 